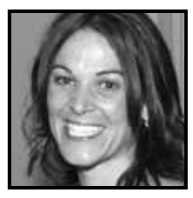

\title{
Lessons From the Field: Creating Sustainable Engagement in Organizational Learning
}

\author{
Ellyn Lyle
}

\section{ABSTRACT}

The philosophies of Join-Up with horses extend to inform theories of learner engagement. Drawing from these theories, and theories in adult education, I discuss paths to creating sustainable engagement of learners within industry-based education initiatives. Embracing a reflexive narrative approach, I consider the efforts of two large organizations to establish and grow learning cultures. Critically deconstructing these applied learning practices, and their successes and failures, reinforces my assumption that deep communication, trustful interaction, and choice are integral to the creation of meaningful and sustainable learning. This assumption leads me to consider the ways in which these philosophical commitments manifest themselves in physical learning spaces.

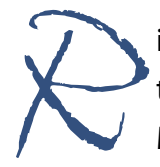

iding embodies a rare friendship in solitude. In the quiet way it carries me through life, it is my metaphor. On horseback, I am never travelling alone. My thoughts, my joys and tensions, are felt keenly, so I'm called upon to pay attention to my own subtleties and exercise care with those who look to me for direction. I must also be awake to learning from those I lead. If I am conscientious and honest, the journey will be more joyous than it might have been. If I grow arrogant or careless, I am apt to find myself in a ditch with mud on my face. Deservedly.

Living my metaphor continues to teach me much about life and myself in it. It also encourages me to think deeply about my role as educator. The centrality of honesty, integrity, and humility in learning with horses provides me with an interesting lens through which I view my other teaching experiences. Monty Roberts, a 
veteran horse trainer and the founder of Equus University, first introduced these values to me. Coined as a term referring to a non-violent approach to starting green horses, the message of Join-Up extends to include philosophies about communication and trust in the learning relationship.

Usually initiated with two year olds, Join-Up frames the way I begin formal training. I bring the horse into a round pen, and I take my place in the middle. With a long, lightweight line, I shoo the horse away from me. Predictably, the horse takes flight in response to what it understands as my aggressive behaviour. As the horse keeps to the rail and lopes circles around the pen, I turn with him, always keeping my shoulders square on him and my eyes locked on his. When he seems to be getting comfortable in this exchange, I abruptly flip the line a few paces in front of him, causing him to reverse and flee in the other direction. What I am communicating is that I am not willing to Join-Up with him, so he best look for a way out of the situation. He does. First, as he flees one way; then, as he flees the other, my behaviour does not change. As Irwin (2007) reminds me, horses don't like ambiguity, so I remain with my shoulders square and my eyes locked on the horse. Again, when the horse seems to be settling into a comfortable gait, I ask him to change direction.

Then I wait and watch carefully for the expected signs. The horse will slow his gait to a jog and his nearest ear invariably flicks inward and points to me. He is saying, "I'm listening." Next, the horse will drop his head, first just below the level of his shoulders, and then almost to the ground. Roberts (2004) says this is the horse's way of saying, "I'm ready to negotiate; if you want to call the meeting, you can be the chair." Finally, the horse will begin to chew and lick, indicating an eagerness to have the conversation. At this point, I look away and drop my shoulders off to a 45-degree angle. My body language communicates that I understand the horse has accepted my invitation and I am ready, too. I then turn my back exposing my own vulnerability and wait. The horse will slow to a walk and tentatively circle in toward me. I remain still with my back turned as the horse approaches me. He will sniff a bit; soon I will feel his breath on my neck, and he will softly nudge my shoulder with his nose: Join-Up. I turn then, eyes averted, and gently rub between the horse's eyes. Then I walk away. The horse follows me. I stop. He puts his nose on my shoulder. I repeat the action. He repeats his response. In this response-based learning, we are communicating deeply. Each of us understands the other, and we are engaged with the process. We are building trust and are ready to begin learning together. Working with people is not unlike working with horses. Our greatest successes come from approaching each other in partnership. This pedagogical framing has deeply influenced my work within learning organizations. 
My first real emersion in a learning organization came well before I was able to name it. Having fled the public school system and then spent years consulting in non-traditional learning environments, I found a chance to return to the classroom full-time. This opportunity was at a local processing plant. The company was a large corporation with more than 800 employees. It had no previous experience offering learning and development, so its approach was one of tempered enthusiasm. Not knowing how the program would evolve, or if it would be sustainable, human resources posted an advertisement for a workplace instructor and decided to leave the program's parameters and development to the successful candidate.

As that successful candidate, I inherited an empty boardroom and 12 weeks to prove the sustainability of the program. Looking back, I guess I knew that there were a few key values that had to be honoured if we were to be successful. Foremost among these was the element of choice. Retrospectively, I know now that assumption is what led me to seek out the human resource manager on my first morning. Although we only spoke briefly, I was relieved to discover that the employees had requested an on-site learning centre, and only those interested in participating would enroll. Confident any potential learner will have chosen to join me, I was eager to meet with the employees.

I dedicated the first two weeks in my new position to having one-to-one chats with each person who expressed interest in the program. All of them carried unique stories of disconnection as well as personal reasons for wanting to re-engage. Although each story was equally important, I remember one with particular clarity.

I was sitting at my makeshift desk, a table in front of a plate glass window, looking out over the front grounds. I was lost in a reverie about my own experiences of disengagement and those shared with me that morning. I was jarred back to present by an impatient knock and the formidable presence of a gargantuan man l'd yet to meet. There was no point inviting him inside as he had already closed half the distance between the door and where I was seated. Noticing the mud on his boots, he stopped, fixed his eyes on me as a little smirk tugged on his red, bearded face, and then stomped his boots clean in the middle of the classroom floor.

"Hope you gotta broom," he said.

"Don't worry about it," I replied. "Have a seat wherever you like."

He picked up a chair as if it were one of those little seats in primary and dropped it within a foot of my desk. 
"Here good?"

"Sure," I replied.

"Don't wanna get too close and get dust on that fancy suit of yours," he goaded.

I asked him what brought him in to see me. He said that he had come to get his "edubacation." Sensing he was having a bit of fun at my expense, I asked what education he was after. He said he wanted to get Grade 12. I explained that we could move forward in one of at least two ways: he could self-identify a level and we'd go from there; or he could complete an assessment and we'd establish his level and build on that. He asked when he could be tested, and I replied that I was available at his convenience.

"No time like the present," he said. "You best git out yer abacus and slates to see whatcha gotta learn me."

I invited him to move to the centre table where he had more room, and I gave him a package that I used to assess the baseline of those I assumed were quite literate, perhaps about a Grade 10 or 11 equivalency. It normally takes about an hour to complete but he handed it to me in 35 minutes. I thanked him and asked when he wanted to come in for a follow-up so we could develop a learning plan.

"What-yer not gonna grade it?"

I explained that I generally completed the assessments after learners left so that I could prepare a recommendation for them.

"Just get out yer red pen, Teach, and tell me how I did."

I invited him to read while I went through his assessment. Instead, he wandered around as I found section after section of his assessment completed and correct. Delighted, I told him that he was ready to begin at G.E.D. preparation and I anticipated that he would breeze through his high school equivalency.

"Geez, Teach, you must be surprised. A big woolly bugger off the farm knowing his $A B C^{\prime}$, huh? Who'da thunk it?"

I replied, "having grown up on 1000 acres not 10 miles from here, I figure there's a few of us hayseeds who can count to ten. Perhaps since you're so bright, we'll see if we 
can give you a little extra-credit work to help you overcome your assumptions." Pre-empting further exchange, I turned my attention back to my desk and left him to find his own way to the door. He sat quietly for a minute before he got up. As he made his way to the door, he barked out a laugh.

"Teach? If you're a farm girl, you probably got some jeans. Why don't you retire that fancy suit and put on some real clothes."

I didn't dare look back or respond for fear l'd laugh. I wanted to create a space for real people to engage meaningfully with learning. Well, it didn't get a whole lot more real than this.

I continued for two weeks to engage prospective learners in deep communication about their goals, anticipated challenges, and ways we could ground their learning. When we opened the doors to the learning centre in the third week, we had 32 students. Together, we created a program that was learner-centred and generative: learners opted in to the program without coercion or recommendation; their programs were developed individually, based on careful needs assessment; the individual learning plans were kept confidential; and there was no reporting mechanism back to human resources or supervisors. Word of the learning environment travelled and enrollment grew. Within six months the 32 had become 60 and by the end of the year more than 100 employees were enrolled. Although the program originated to help employees earn high school equivalency diplomas, the needs were as diverse as the learners, so the programs evolved to include a range of courses from adult basic education and essential skills to support with master-level degrees.

Having based the program heavily on Freirian philosophy, I assumed it would empower employees, improve their opportunities for advancement, boost morale, and position the company as a place of opportunity. Further, by offering programs for all levels of learning and staffing, I hoped the learning centre would transcend traditional barriers and become a place relatively free of rank. Long before we could determine our overall effectiveness as a learning centre, we saw evidence of success.

I was living in a world of hats. I realized this almost immediately after taking the job. You see, the front-line employees wore only white hats. The white hat suggested rank, pay level, and lack of power. The green hats were worn by maintenance. They were items of envy because they were not among the hated blue hats but essential enough to production to be spared wearing white ones. The blue hats were resented by all who didn't 
wear them. Under them were the supervisors, a most unenviable position in my estimation. Having the appearance of power to those below them and only obligation to those above them, supervisors represented the highest turnover and lowest engagement. Then there were the no hats. These folks were management and generally regarded with disdain by all who wore hats. The hats (or lack thereof) were evident on the floor, in the yard, and at lunch. They determined who sat with whom on breaks and even where you parked your vehicle. The hats had amazing power. Their power was so awesome that, in checking the hats at the door, the learning centre became a place of equality. I'll never forget the day that it all began to change: a senior manager who had been in his role for more than 30 years joined the learning centre. Of course, we had met privately to establish a baseline and to build his learning plan, but the other learners did not know that a manager was about to join them. The first day he walked in to the classroom, the atmosphere grew thick with tension. Two of his employees already at the table looked at me with a combination of suspicion and fear. I offered them a quick glance of reassurance as I welcomed their manager to the table. He sensed the tension and handled it brilliantly. He knew I would not disclose why he was at the learning centre, so he simply asked if there was any room at the table for a man with only Grade 8 education. As looks of surprise replaced looks of suspicion, the barriers weakened. Within a week, the manager asked one of his employees for a bit of extra help with his fractions. A month later, they were poking fun at each other as the manager struggled to make sense of algebra. Overhearing the conversation, I suggested that they think of their chemical formulas as algebra and work backward to see how unknown variables are useful. Their learning became both collaborative and relevant, and more barriers fell away. Six weeks after that first manager walked through the door, two more followed. In a world so strictly governed by rank, this egalitarianism was radical.

I was delighted that the learning centre was becoming a place free of rank. Founded on choice, deep communication, and trust, it was proving itself to be both relevant and sustainable. The business, however, required that it also quantify its value. I decided to conduct surveys and hold informal interviews to determine if the program was successfully meeting the needs of both individual learners and the organization. The results were clear: as individual knowledge grew, collective organizational knowledge was growing; this new learning boosted the performance of individuals, departments, and the organization; supervisors reported significant improvement in morale; and turnover among the learner population was two percent compared with the 11 percent among non-learners. These returns, together with the breakdown in the caste system, indicated that we were not only achieving a quantifiable return on the company investment, but also helping the company transition to a learning organization. 
So far, I've focussed primarily on how the learners and I created spaces for them to Join-Up with me on their learning paths. But the company also made some important contributions that facilitated this process. For example, the program was entirely employer-funded, yet it was completely employee self-selected and governed. Additionally, the employees were compensated in one of two ways to attend: they were either paid half of their regular hourly wage to attend off shift, or they were permitted one two-hour learning period twice weekly during their paid shifts. The philosophy behind this compensation was that learning benefits both the employee and employer so it should be cost shared. Presumably coming back to school on days off involved fuel to drive in, childcare, and time away from other part-time work. Therefore, for every two hours spent in learning on the employee's own time, the employer paid one hour's wage. Those employees who worked the same hours as the centre was open, and who were therefore unable to come to school, were permitted four hours weekly of paid study time. The trade-off for this latter group was that there was no extra compensation available to them for time spent in learning. Perhaps the company's most important contribution was its distance. Other than receiving attendance reports to facilitate compensation, the organization was wholly uninvolved. There were no strings, no payback clauses, no reporting mechanisms, and no loopholes. Learning became personally meaningful and relevant.

This type of program also presented some challenges. Entirely employerfunded programs are often cost prohibitive, which make them difficult to sustain for many organizations, particularly small- and medium-sized businesses. In addition to the salary of a full-time teacher and the cost-share initiative with employees, the program required extensive infrastructure: classroom, computers, and learning materials. The organization must also have a large enough employee base to cover those participant-learners who leave the floor to study in two-hour blocks of time. Finally, scheduling must be agile enough to accommodate the diverse needs of many employees. Both financial ability and staffing agility demand a high level of commitment from the learning organization.

In this particular company, though, the program was a tremendous success for everyone involved: in the four years I was with them, more than 250 learners succeeded in meeting their goals across more than 18 programs; the organization received national and international attention for its commitment to workplace education while benefitting from more skilled and engaged employees; and I found a space where education was collaborative, personally meaningful, and relevant. 
In our fourth year, the program had brought benefits to the company significant enough that I was offered the opportunity to move to its corporate office and develop the model of learning further so that it might be introduced in the corporation's six other business units and made available to its more than 7,000 employees. Excited about the possibilities, I accepted the opportunity to join the corporate team as its Organizational Development Specialist. After training a replacement for our learning centre, I transitioned to the corporate offices. Almost immediately, though, I recognized serious barriers to successful inter-business implementation.

At the corporate level, the company did not have the framework to be a learning organization. First, the corporate headquarters were independent of all business units and, by design, physically removed from all business sites. As such, any individual learning was contained in silos and therefore could not congruously contribute to organizational knowledge. Likewise, because the learning occurred in silos, it was unable to affect overall organizational performance. Finally, because the corporate level was primarily executive-level staff, it was not organically involved with practical operations of the individual business units. Perhaps the most serious barrier to effectively leveraging learning across the businesses was situating it within the corporate headquarters. An elite distant unknown to most of the businesses and their people, the corporate office did not have the trust of its independent units. It was regarded with disdain and reputed to know little about the ground-level operations of each business and therefore believed to implement one problematic solution after another.

Had the actual learning model created in that first business been shared with each of the other businesses and then grown organically in-house, thereby honouring the principles on which it was founded, there might have been an opportunity for success. Unfortunately, because the company was determined to leverage one solution through one person to multiple businesses all across North America, I could not envision paths to successful Join-Up. Having recognized this incongruence, I brought my concerns to my executive team, where I learned that the structure was unlikely to change. With no foreseeable solution, and unwilling to become mired in an ineffective system, I tendered my resignation.

Although I wasn't able to accomplish at the corporate level what l'd hoped, my experience there led me to an important realization: learning initiatives seemed to be most successful when they were grown organically and collaboratively. Eager to move to a new space that had the capacity to embrace this model, I accepted an offer to join a global Human Resource firm as its National Manager of Learning and 
Development. My directive was two-fold: to manage the training opportunities and teams aligned to existing external clients, and to inform the growth of a new learning and development service that the company would offer nationally.

Unlike the processing plant, where learning was entirely internally focussed, this new organization had two learning mandates: to promote learning and development of its own employees, and to sell learning and development services externally.

From an internal perspective, the company seemed to be a solid example of industry best practice. It offered its employees an above industry standard of 10 paid training days and 2,000 dollars tuition reimbursement per calendar year. Employees also had access to more than 4,000 electronic courses and e-books to assist them with personal and professional development.

In addition to these self-directed learning opportunities, employees participated in face-to-face training developed and delivered by the company's internal training team. These courses were designed to make transparent performance management, engagement, operational changes, and strategic initiatives.

Offering opportunities that aligned employee development to organizational growth allowed the company to optimize both individual and collective knowledge. By making learning plans a central part of its performance management system, the company focussed on both employee development and organizational performance. These practices, as well as its use of engagement surveys to systematically collect and respond to employee feedback, suggested the company was a learning organization.

As one of its newest employees, I was pleased that the company created spaces for its employees to engage with learning in personally meaningful ways. As its national manager of external training, though, I was tasked with a different challenge.

I had just completed my doctoral residency and was delighted to be offered a position with a global firm newly established back home. Although I didn't have all the details of my new role, I knew that the company had a sizeable learning and development contract that was in jeopardy and the executive was looking for someone with a strong background in education and business management to create realignment and grow the external learning department. 
When I arrived in my new office, I found a damaged team, disappointed client, and disintegrated curricula. Wanting to understand the brokenness, I met individually with each member of my new team. I heard repeatedly that misalignment with previous management had left them feeling overworked and under resourced. Since the removal of that leadership, each person named feelings of abandonment by the company. With the permission of each who confided in me, I asked if we could meet as a group to collaboratively plan moving forward.

With them onside, we got together to discuss two explicit objectives: determine how we could contribute individually, and identify those areas where we required support. This approach helped to create transparency and alignment. Next, we brainstormed requirements for success. This exercise helped us to create a shared vision of learning and development. Third, we negotiated role expectations so each of us had clarity and, as a team, we could identify gaps. At this point, we arrived at a place where individual roles were evolving, a shared vision of learning and development was budding, and gaps were being uncovered. Implicitly, we were communicating our way to trustful relationships that would establish sustainable commitment to working together.

Next, we turned our attention to rebuilding client confidence. We met with key stakeholders so that we could understand better their unique requirements and then collaboratively determine ways to meet their objectives. Both the clients and my team were delighted to be involved in planning and expressed excitement about continued partnership. We were on our way to joining-up, but we needed new curricula.

The current curricula were highly Americanized and laden with case studies situated in the private sector. Considering the clients were in the Canadian public sector, we decided to throw everything out and begin fresh. Guided by the principles of Join-Up, we established several meetings at which my team and our client could collaboratively identify areas for professional development. Honouring deep communication, trust, and choice, we all participated in identifying the intent of the new curricula. Once this intent was articulated, our clients began a communication campaign to reintroduce learning and development to its employees, and our team began the task of development.

After months of collaboration and research, we had a canon of 24 new professional development seminars when we kicked off training that fall. Three years and more than 400 sessions later, the learning and development team continues to honour communication and choice: advisory partnerships meet monthly to discuss learning requirements, and learners are encouraged to complete evaluations after all seminars and suggest areas for improvement. These evaluations are collated and analyzed annually, and 
both the raw data and the executive summaries are forwarded to clients. The relationship of trust grew and the clients committed to transitioning from a year-to-year agreement to a long-term service delivery commitment.

I had been hired first to create realignment, foster engagement, and build sustainable client relationships, and second to grow our professional development seminars into curricula that could be sold nationally to a diverse clientele. Having risen to the challenge of the first task, I turned my attention to the second one.

In addition to managing the requirements of our existing clients, I was asked to become a member of an executive advisory group that would lead the development of learning as an externally marketable product. Despite the individual and collective passion, there was immediate misalignment: the project manager insisted on accountability and timeliness of delivery; the product manager was focussed on branding and marketing for consistency and repeatability; the training manager was driven by engaging sales and providing delivery collateral for a network of contract trainers; the director was committed to collaboration so that various business units could successfully coexist while meaningfully contributing their areas of expertise to the development of a new product; the executive vice-president was focussed on long-term fit for market growth; and I was determined that we bring nothing less than theoretically sound and practice-proven programs to our clients.

For my part, which is really all I can speak to, I struggled with conceptualizing learning as a product to be sold. Additionally, bringing to the team curricular expertise, I disagreed with the notion that all training should be standardized and sold as a boxed solution. My arguments in favour of organically grown learning initiatives, the engagement imperative, and curricular integrity were outweighed by the seduction of a low-maintenance, one-size-fits-all approach to securing a high profit margin.

Committed to contributing and determined to encourage what I assumed to be best practice, I agreed to provide a generic curricula on the condition that all contract trainers would be educated in subject matter and prepared by my team for a dialogic approach that would let them customize the curricula to suit the needs of individual clients. My team worked tirelessly to meet our commitment and submitted a solid canon of professional development programs. Once the collateral was delivered, the advisory group decided that training the trainers was too costly, and opted instead to use scripted facilitator guides. This approach was so incongruent with the intent of the programs that I went on record as strongly opposed to this 
new direction. Although I continued to meet with the advisory group and inform development of the company's external learning product, I did so as the voice that questioned an approach that positioned learning as a static commodity. I cautioned that such a one-size-fits-all approach was decidedly incongruent with the principles of adult education and counter to the market's desire to have customizable learning opportunities responsive to unique business cultures. The appeal of a greater profit margin won, and the product was brought to market as a boxed solution to be delivered by facilitators guided only by script.

Now in its second year, external learning has failed to entice even existing clients and has lost the support of the executive. Internal resources were reassigned and divisiveness in our group continued to fester. The presence of competing agendas continued to create misalignment, and the lack of process resulted in unpredictability and inconsistency. As this space became a breeding ground for misunderstanding, communication was neither safe nor respectful. Trust was not achieved.

The absence of effective communication, the breakdown of trust, and the impossibility of choice impeded Join-Up within our executive advisory group. Some people left the initiative; others were removed. External learning, as a marketable product, continues to fall desperately short of anticipated revenue. Its lack of success to date, I assume, is partly due to the sales and marketing model that positions learning as a product and does not understand it as a process. ${ }^{1}$ I also assume that the lack of market uptake is due in part to the product itself, which does not present learning as organic, collaborative, and dialogic.

Critically deconstructing these applied learning practices, and their successes and failures, reinforces my assumption that deep communication, trustful interaction, and choice are integral to the creation of meaningful and sustainable learning. Wanting to understand the practical implications of this assumption led me to consider how these philosophical commitments manifest themselves in the physical learning spaces.

Supported by the work of several scholars, ${ }^{2}$ I believe that teaching emerges from who we are. For that reason, it's imperative that I am awake to the ways in which my theoretical beliefs are operating in my teaching. Although each of us crafts a distinct practice, l've found commonalities in the characteristics we embody as we try to create spaces for our learners to Join-Up. I understand these tendencies as falling loosely under four themes: communication, democracy, responsiveness, and integrity. 
Healthy learning relationships are made more meaningful through open communication. I think, as teachers, we are really good at articulating our expectations and then providing feedback. These bits of communication represent the outgoing messages and are clearly related to our expected outcomes. Perhaps more subtle, though equally central, is careful listening. I wonder if we hear our students with the same clarity that we speak to them? If we are to create spaces for Join-Up, the proffered learning ought to be born of the students' goals and honour their lived experiences. Although we often have outcomes that must be met, there are multiple paths that will lead us to them. A commitment to deep and continuous communication sets us up for an engaged and successful learning experience.

Teaching for democracy is also essential. Based not in equality of power, as that would be dishonest, this democracy is evident in the delicate relationship between a teacher's ability to lead and her willingness to follow. If I am to create personally meaningful learning for each of my students, I need to take a seat among them and be open to learning through their experiences. This pedagogical approach does not pretend away my position of power; it encourages me to share it. In the sharing, the learning environment becomes a space of negotiation, and the learning unfolds as a dynamic and reciprocal process.

Responsiveness is born of my commitment to communication and democracy. It is validating for learners as it allows them voice and agency. It frames their experiences in a way that concurrently encourages them to seek meaning in their learning and collaboratively inform its development. In doing so, it also encourages accountability. In co-authoring their learning, students are sharing ownership in the whole process: curricula, assignments, and assessment. Even bound by predetermined outcomes, this practice may lead us to paths we were previously unable to imagine-to places where we reconceptualize the learning relationship and create spaces for Join-Up.

At the heart of integrity in learning is a commitment to honesty, fairness, and respect. Each of us, teacher and student, is a learner at heart. We approach scholarship with unique experiences and knowledge that can enrich each other and augment our own learning. I must acknowledge the power inherent in my role as teacher but never allow it to overshadow the opportunity to learn with my students.

I think it is also helpful to name those characteristics of place that encourage learners to Join-Up with learning. Influenced by Palmer (1998), I understand these tendencies as being situated within five thematic areas: bounded openness; charged affability; voice; solitude within community; and deliberate wakefulness. 
Space should be both bounded and open. A learning environment must have enough parameters to make it safe; otherwise, it risks becoming a void. Both in my reading of Palmer (1998) and in my own studies of praxis, these parameters may take the form of desired outcomes, subjects for study, relevant materials, and negotiated rules for safe learning spaces.

The learning environment should be both affable and charged. The risk in creating a learning environment that is open is that the competing agendas and diverse passions of those participating may grow the space into a place of potentially risky discovery. Caution must be partnered with passion so that learners are safe to engage in the learning community without fear of being silenced, judged, or lost.

Third, and certainly closely related, the learning space should honour voice. In addition to creating space for the voice of each person participating in the learning environment, we should also take care to foster the development of a collective voice. While the former encourages individual criticality, the latter fosters collaboration.

Similarly, learning spaces are most effective when they provide room for individual reflection and dialogic learning. Solitude encourages reflexive contemplation, while conversation provides context for our experience and epistemological claims.

Finally, if we are to Join-Up with learning, we have to be awake to individual interests and power imbalances. This wakefulness requires that we deconstruct not only the positions each of us takes, but also pull at the threads of those positions to reveal the underlying interests. Only when we look for the undercurrents of power and privilege can we hope to generate less oppressive paths to learning.

Each of us comes to learning with varied and diverse lived experiences that inform not only what we know, but also how we know. To deny these experiences, or bar them from the learning environment, is detrimental to those trying to engage with learning. Further, it is apt to result in conditions incongruent with Join-Up, thereby damaging the potential for personally meaningful and sustainable learning. In an attempt to champion spaces for students to engage more fully, I continue to maintain that education is made more joyful when approached with an undivided heart. 


\section{Notes}

1. Drawing from the work of Argyris \& Schön, 1995; Bruner, 1977, 1986, 1990; Jarvis, 1987; Kolb, 1984; Lave \& Wenger, 1991; and Smith, 1999, I understand learning conceptualized as a product to be driven by outcomes and measured by observable changes in behaviour. It is assessed in terms of change and valued by getting the most change for the least investment. Learning conceptualized as a process exalts the importance of the journey and acknowledges that the variables of human capacity and lived experience often make learning outcomes unknown. Still change centric, this conceptualization views learning as openended and tends to juxtapose the purpose and process of learning while questioning the influence of the systems on this matrix.

2. Brookes, 1992; Cole \& Knowles, 2000, 2001; Ellis \& Bochner, 2000; Ellsworth, 1997; Foucault, 1984; Knowles, 2001; Knowles, Cole, with Presswood, 2008; and Palmer, 1993, 1998.

\section{References}

Argyris, C., \& Schön, D.A. (1995). Organizational learning II: Theory, method, and practise. Boston: Addison Wesley.

Brookes, A. L. (1992). Feminist pedagogy: An autobiographical approach. Halifax, NS: Fernwood.

Bruner, J. (1977). The process of education. Cambridge, MA: Harvard University Press.

Bruner, J. (1986). Actual minds, possible worlds. Cambridge, MA: Harvard University Press.

Bruner, J. (1990). Acts of meaning. Cambridge, MA: Harvard University Press.

Cole, A. L., \& Knowles, J. G. (2000). Researching teaching: Exploring teacher development through reflexive inquiry. Needham Heights, MA: Pearson Education.

Cole, A. L., \& Knowles, J. G. (Eds.) (2001). Lives in context: The art of life history research. Lanham, MD: Altamira Press

Ellis, C., \& Bochner, A. P. (2000). Autoethnography, personal narrative, reflexivity: Researcher as subject. In N. K. Denzin \& Y.
S. Lincoln (Eds.), Handbook of qualitative research (2nd ed., pp. 733-768). Thousand Oaks, CA: Sage.

Ellsworth, E. (1997). Teaching positions: Difference, pedagogy, and the power of address. New York: Teachers College Press.

Foucault, M. (1984). What is enlightenment? In P. Rabinow (Ed.), Foucault Reader (pp. 3-51). New York: Pantheon Books.

Irwin, C. (2007). Horses don't lie. Winnipeg, MB: Great Plains.

Jarvis, P. (1987). Adult learning in the social context. London: Routledge.

Knowles, J.G. (2001). Writing place, wondering pedagogy. In L. Neilsen, A. Cole, \& J.G. Knowles (Eds.), The art of writing inquiry (pp. 89-99). Halifax, NS: Backalong Books.

Knowles, J. G., \& Cole, A. L. with Presswood, C.S. (2008). Through preservice teachers' eyes: Exploring field experiences through narrative and inquiry. Halifax, NS: Backalong Books. 
Kolb, D. A. (1984). Experiential learning. Englewood Cliffs, NJ: Prentice Hall.

Lave, J., \& Wenger, E. (1991). Situated learning: Legitimate peripheral participation. Cambridge, MA: University of Cambridge Press.

Palmer, P. (1993). To know as we are known. San Francisco: Harper Collins.
Palmer, P. (1998). The courage to teach. San Francisco: Jossey-Bass.

Roberts, M. (2004). Join-up ${ }^{\mathrm{TM}}$. Monty and Pat Roberts Inc. DVD.

Smith, M. K. (1999) Learning theory, the encyclopedia of informal education (Fall 2009). Retrieved March 28, 2012, from www. infed.org/biblio/b-learn.htm.

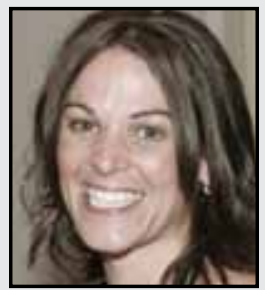

Ellyn Lyle has spent the past decade fostering spaces for adult and continuing education in centres for workplace learning and professional development. Deeply committed to applied learning, she works hard to create spaces for learners to engage meaningfully with their studies. She champions critical thought and positions education as change. Her current research interests include: reflexive narrative, transdisciplinary approaches to improving praxis, critical pedagogy, adult education, organizational learning, and leadership. Ellyn holds the following degrees: B.A., B.Ed., M.Ed., and Ph.D. She has also been awarded the CTDP designation by the Canadian Society for Training and Development.

\section{LINKTO:}

http://www.organizationaleffectivenessandlearning.ca 